University of Nebraska - Lincoln

DigitalCommons@University of Nebraska - Lincoln

USDA National Wildlife Research Center - Staff Publications
U.S. Department of Agriculture: Animal and Plant Health Inspection Service

February 2007

\title{
Feral swine management for conservation of an imperiled wetland habitat: Florida's vanishing seepage slopes
}

Richard M. Engeman

USDA-APHIS-Wildlife Services, s_r100@yahoo.com

Amanda Stevens

Eglin AFB Natural Resources

John Allen

USDA/APHIS/WS

Jon Dunlap

USDA/APHIS/WS

Marty Dunlap

USDA/APHIS/WS

See next page for additional authors

Follow this and additional works at: https://digitalcommons.unl.edu/icwdm_usdanwrc

Part of the Environmental Sciences Commons

Engeman, Richard M.; Stevens, Amanda; Allen, John; Dunlap, Jon; Dunlap, Marty; Teague, Dennis; and Constantin, Bernice, "Feral swine management for conservation of an imperiled wetland habitat: Florida's vanishing seepage slopes" (2007). USDA National Wildlife Research Center - Staff Publications. 407. https://digitalcommons.unl.edu/icwdm_usdanwrc/407

This Article is brought to you for free and open access by the U.S. Department of Agriculture: Animal and Plant Health Inspection Service at DigitalCommons@University of Nebraska - Lincoln. It has been accepted for inclusion in USDA National Wildlife Research Center - Staff Publications by an authorized administrator of DigitalCommons@University of Nebraska - Lincoln. 


\section{Authors}

Richard M. Engeman, Amanda Stevens, John Allen, Jon Dunlap, Marty Dunlap, Dennis Teague, and Bernice Constantin 


\title{
Feral swine management for conservation of an imperiled wetland habitat: Florida's vanishing seepage slopes
}

\author{
Richard M. Engeman ${ }^{a, *}$, Amanda Stevens ${ }^{b}$, John Allen ${ }^{c}$, John Dunlap ${ }^{c}$, Marty Daniel $^{c}$, \\ Dennis Teague ${ }^{b}$, Bernice Constantin ${ }^{c}$
}

${ }^{a}$ National Wildlife Research Center, 4101 LaPorte Ave, Fort Collins, CO 80521-2154, USA

${ }^{\mathrm{b}}$ Eglin AFB Natural Resources, 107 Hwy 85 N., Niceville, FL 32578, USA

${ }^{\mathrm{C}}$ USDA/APHIS/WS, 2820 East University Ave., Gainesuille, FL 32641, USA

\section{A R T I C L E I N F O}

Article history:

Received 16 May 2006

Received in revised form

21 August 2006

Accepted 31 August 2006

Available online 27 October 2006

Keywords:

Bioeconomics

Damage management

Habitat valuation

Invasive species

Sus scrofa

\begin{abstract}
A B S T R A C T
Only $1 \%$ of the original extent of Florida's seepage slope habitat remains, with Eglin Air Force Base containing some of the largest tracts. Feral swine damage is one of the greatest threats to this wetland habitat. We conducted a multi-year study to evaluate the impacts of sport hunting and supplemental swine removal on damage to seepage slopes. Prior to initiation of removal in 2003, swine damage to seepage slopes in the portion of the base closed to hunting averaged $25.0 \%$, over twice the $10.9 \%$ losses in the portion open to hunting. After less than one year of supplemental removal, damage in the closed-to-hunting area dropped to $7.2 \%$. Although supplemental removal was not applied in the open hunting area, damage dropped significantly to $5.6 \%$, statistically indistinguishable from the swine-controlled (closed) portion. After another year of removal, average damage in the closed hunting area dropped further to $5.6 \%$, while the open hunting area dropped to $4.3 \%$, again statistically indistinguishable. Even though removal was only applied to the area closed to hunting, it also produced damage reductions in the open hunting area, as swine were free to move among areas. Declines in damage following implementation of removal corresponded with large drops in swine population indices for the base. Economic valuations of seepage slope damage losses demonstrated substantial benefit-cost ratios for application of removal. Prior to removal, the combined value of swine damage to seepage slopes in areas open and closed to hunting was estimated at $\$ 5.3$ million. After only 1.7 years of removal, the value of damage losses was reduced by nearly $\$ 4$ million to $\$ 1.5$ million. The benefit-cost ratio over the 1.7 years of removal was an impressive 27.5. Moreover, the economic benefits of removal exceeded the costs 55.2-fold for the first year, when management impact would be greatest.
\end{abstract}

Published by Elsevier Ltd.

\section{Introduction}

Feral swine Sus scrofa can be a highly destructive exotic species that degrades habitats, preys on native species, and competes with native species (Choquenot et al., 1996; Taft, 1999; US Department of Agriculture, 1999; Seward et al., 2004). They also harbor a number of diseases transmittable to wildlife, livestock or humans (e.g., Conger et al., 1999; Romero and Meade, 1999; Taft, 1999). Florida joins Hawaii as the two states of the United States with the most severe invasive species problems (US Congress, 1993), and swine were one of the first invasive exotic species to take hold in Florida after their intro-

\footnotetext{
* Corresponding author: Tel.: +1 970266 6091; fax: +1 9702666089 .

E-mail address: richard.m.engeman@aphis.usda.gov (R.M. Engeman). 0006-3207/\$ - see front matter Published by Elsevier Ltd. doi:10.1016/j.biocon.2006.08.033
} 
duction by DeSoto in 1539 (Towne and Wentworth, 1950). The species possesses the highest reproductive potential of any large mammal in North America (Wood and Barrett, 1979; Hellgren, 1999) and, with subsequent introductions, the range of feral swine in the US continues to expand (Gipson et al., 1997). Feral swine currently inhabit many areas in such large numbers that they adversely impact wildland and agricultural ecosystems. Feral swine have been implicated by some as the single greatest vertebrate modifier of natural plant communities (Bratton, 1977; Wood and Barrett, 1979). Rooting may damage population structures of plants, set back succession, and change species composition (Bratton, 1977). Swine have been implicated for facilitating dieback disease in native vegetation by spreading rootrot fungus (Phytophthora cinnamomi) (Kliejunas and Ko, 1976). Habitat damage by swine is most pronounced in wet environments (e.g., Choquenot et al., 1996). We focus here on swine damage to a unique and disappearing wetland habitat in Florida: seepage slopes (FNAI, 1990).

Seepage slopes are wetlands at the base of a slope, characterized by boggy grassy meadows or shrub thickets (FNAI, 1990). They are maintained by downslope groundwater seepage resulting from a water table perched above an impermeable layer of clay or rock. Seepage slope soils are saturated but are rarely inundated by water. Many rare and endemic species are found on seepage slopes including insectivorous plants and several species of orchids and lilies (Florida Natural Areas Inventory [FNAI] 1990, Kindell et al., 1997; Harper et al., 1998). Only $1 \%$ of the original extent of seepage slopes in Florida is estimated to remain, with Eglin Air Force Base (Eglin AFB) in northeast Florida containing some of the largest remaining tracks, thus making the base particularly important for conservation of this habitat (FNAI, 1990; Kindell et al., 1997).

One of the major threats to the seepage slopes on Eglin AFB is damage by feral swine (Kindell et al., 1997; United States Air Force, 2002). We carried out a multi-year investigation to: (1) assess the extent of swine damage to seepage slopes on Eglin AFB, (2) evaluate the impacts of sport hunting and swine removal towards damage reduction, (3) apply economic valuations to damage, (4) conduct bioeconomic analyses, including benefit-cost ratios for swine removal.

\section{Methods}

\subsection{Study area, site selection and observation methods}

Eglin AFB covers a large area $(187,780 \mathrm{ha}, \approx 82 \mathrm{~km} \mathrm{E-W}$ and $31 \mathrm{~km} \mathrm{~N}-\mathrm{S}$ ). Approximately $86 \%$ of Eglin AFB is forested, $12 \%$ dedicated solely to military activities (i.e., airfields, cleared test ranges, test sites, rights-of-way, and administrative areas), and the remaining $2 \%$ is comprised of water, marshes and barrier island (Kindell et al., 1997). Eglin AFB lands are used extensively for recreation, including sport hunting for a variety of bird and mammal species. Approximately half of the base may be hunted during various seasons, with opportunities to hunt feral swine during seasons running from mid-October through mid-February (by varying hunting methods, with a three week break for small game season in January). Swine are considered feral animals on Eglin AFB and are not subject to bag limits (United States Air Force, 2002).

In spring of 2003, we randomly selected 28 of the 237 known seepage slopes from across the base for study. To evaluate the impact of sport hunting on swine damage to seepage slopes, half of these study seepage slopes were randomly selected from areas open to public hunting, and half in areas closed to hunting. Damage and habitat variables were measured at 20 randomly selected $1 \mathrm{~m}^{2}$ plots within each seepage slope. Seepage slopes were observed in May/June of 2003, 2004, and 2005. The same plot locations were used on each observation occasion to optimize inferences over time (Ryan and Heyward, 2003).

In each $1 \mathrm{~m}^{2}$ plot at each seepage slope, the percent cover of swine damage and presence/absence of root exposure were measured as direct observations of swine damage. Swine damage was defined by broken vegetative surface within the $1 \mathrm{~m}^{2}$ plot caused by swine rooting or tracks. A number of additional vegetation and habitat measures (Table 1 ) were made in each plot that might relate to feral swine impacts, although each of these measures is influenced by many environmental factors. The metrics for the observations made in each plot included percent cover (measured visually by assignment to one of nine percentage categories), presence/absence, and stem density, depending on the variable being measured (Table 1). The total number of plant species observed in each plot was also recorded. Among the measured vegetative variables listed in Table 1, the percent cover of toothache grass Ctenium aromaticum, wiregrass Aristida beyrichiana, and herbaceous cover (forbs and graminoids) were of particular interest, as coverage by these grasses is an indicator of seepage slope health (Harper et al., 1998). Also of particular interest among the variables in Table 1 were several state-listed threatened and endangered species including: whitetop pitcher plant Sarracenia leucophylla, red-flowered pitcher plant Sarracenia rubra, spoonflower Peltandra sagittifolia, as well as species groupings, such as bogbuttons and asters that could include other state-listed species.

\subsection{Swine population indices}

Feral swine were monitored using a passive tracking index methodology similar in principle to the methods successfully applied by Engeman et al. (2001) to a state park in eastern Florida. Because Eglin AFB covers a large area, tracking plot construction was adjusted to allow efficient sampling on a much larger scale. Tracking plots were located randomly along roads throughout Eglin AFB as an efficient design for sampling the area (Pearson and Ruggiero, 2003). The plots were created and their tracking surfaces prepared by dragging $2 \mathrm{~m}$-wide chain loops behind a pickup truck for $1.6 \mathrm{~km}$. The minimal distance between plots was $1.6 \mathrm{~km}$. Plots were inspected the following day and the number of swine intrusions (number of sets of tracks) were recorded in the same manner as Engeman et al. (2001) for smaller plots and landscapes. The process of preparing the tracking surfaces and recording the number of swine intrusions was repeated for three consecutive days. Plot locations were recorded by GPS and the same plot locations were used on each sampling occasion (e.g., Ryan and Heyward, 2003; Engeman, 2005). Tracking data were collected from 17 permanent plot 
Table 1 - Damage, vegetative, and habitat variables measured at each of twenty $1 \mathrm{~m}^{2}$ plots on 28 seepage slopes at Eglin Air Force Base, Florida

Value contributed by each seepage slope for analyses

\begin{tabular}{|c|c|c|}
\hline Swine damage & $\%$ Cover & Average \% cover over 20 plots \\
\hline Root exposure & Presence/absence & $\%$ of 20 plots where present \\
\hline Plant species & \# Plant species in plot & Average \# species over 20 plots \\
\hline Toothache grass Ctenium aromaticum & $\%$ Cover & Average $\%$ cover over 20 plots \\
\hline Wiregrass Aristida beyrichiana & \% Cover & Average $\%$ Cover over 20 plots \\
\hline Panicgrass Dichanthelium spp. & \% Cover & Average \% Cover over 20 plots \\
\hline Other graminoids (grasses, sedges, rushes) & $\%$ Cover & Average \% cover over 20 plots \\
\hline Nongraminoids (forbs - nonwoody plants) & \% Cover & Average $\%$ cover over 20 plots \\
\hline Woody plants & $\%$ Cover & Average $\%$ cover over 20 plots \\
\hline Saw palmetto Serenoa repens & \% Cover & Average \% cover over 20 plots \\
\hline Total vegetative cover & $\%$ Cover & Average $\%$ cover over 20 plots \\
\hline Litter & $\%$ cover & Average $\%$ cover over 20 plots \\
\hline Bare ground & $\%$ Cover & Average $\%$ cover over 20 plots \\
\hline Spoonflower Peltandra sagittifolia & Presence/absence & $\%$ of 20 plots where present \\
\hline Whitetop pitcher plant Sarracenia leucophylla & Presence/absence & $\%$ of 20 plots where present \\
\hline Red-flowered pitcher plant Sarracenia rubra & Presence/absence & $\%$ of 20 plots where present \\
\hline Yellow pitcher plant Sarracenia flava & Presence/absence & $\%$ of 20 plots where present \\
\hline Parrot pitcher plant Sarracenia psittacina & Presence/absence & $\%$ of 20 plots where present \\
\hline Pink sundew Drosera capillaris & Presence/absence & $\%$ of 20 plots where present \\
\hline Dew-threads Drosera filiformis, D. intermedia & Presence/absence & $\%$ of 20 plots where present \\
\hline Thistleleaf aster Eurybia eryngiifolia & Presence/absence & $\%$ of 20 plots where present \\
\hline General asters Asteraceae family & Presence/absence & $\%$ of 20 plots where present \\
\hline Hummingbird flower Macranthera flammea & Presence/absence & $\%$ of 20 plots where present \\
\hline Spaghnum moss Spaghnum spp. & Presence/absence & $\%$ of 20 plots where present \\
\hline Butterworts Pinguicula spp & Presence/absence & $\%$ of 20 plots where present \\
\hline Clubmosses Lycopodium spp. & Presence/absence & $\%$ of 20 plots where present \\
\hline Hatpins/bogbuttons Eriocaulon spp.Lachnocaulon spp. & Presence/absence & $\%$ of 20 plots where present \\
\hline Orchids & Presence/absence & $\%$ of 20 plots where present \\
\hline Exotic plants & Presence/absence & $\%$ of 20 plots where present \\
\hline Red titi Cyrilla racemiflora & Stem density & Average stem density over 20 plots \\
\hline Black titi Cliftonia monophylla & Stem density & Average stem density over 20 plots \\
\hline Gallberry Ilex glabra & Stem density & Average stem density over 20 plots \\
\hline Largeleaf gallberry Ilex coriacea & Stem density & Average stem density over 20 plots \\
\hline Longleaf pine Pinus palustris & Stem density & Average stem density over 20 plots \\
\hline Slash pine Pinus elliottii & Stem density & Average stem density over 20 plots \\
\hline Charred stems & Presence/absence & $\%$ of 20 plots where present \\
\hline Upland species & Presence/absence & $\%$ of 20 plots where present \\
\hline
\end{tabular}

locations in September 2003 prior to implementation of swine removal, and subsequently from those same plots, plus an additional 11 (28 total) in September 2004 and 2005, after one and two years of removal.

\subsection{Swine removal}

After all 28 seepage slopes had been sampled and swine index data collected for 2003, swine removal was applied to the portion of Eglin AFB closed to hunting. Removal was initiated in fall 2003 and has continued to the present by agreement with US Department of Agriculture/Wildlife Services (WS), the Federal agency responsible for managing conflicts with wildlife (US Department of Agriculture, 1997). WS uses only approved and humane methods to euthanize animals, which conform to the guidelines laid out in the 2000 Report of the American Veterinary Medical Association Panel on Euthanasia (American Veterinary Medical Association, 2001) and set forth as agency policy in USDA/APHIS/WS Directive 2.505. Swine were primarily removed by capture in pen traps and euthanized, but some were removed by control hunting (not sport hunting).

\subsection{Data analyses}

The seepage slopes were the experimental units for analytical purposes, with the 20 randomly located $1 \mathrm{~m}^{2}$ plots providing unbiased estimates of the variables used in the analyses (e.g., Thompson, 2002). The mean cover of swine damage across the twenty $1 \mathrm{~m}^{2}$ plots and the percent of those plots with exposed roots for each seepage slope were analyzed as a two-factor repeated measures design (e.g., Winer, 1971), with sport hunting and years as the fixed effects. Seepage slope was a random effect nested in area of open or closed hunting. The data were analyzed in a mixed linear model framework (McLean et al., 1991; Wolfinger et al., 1991) using SAS PROC MIXED with restricted maximum likelihood estimation (REML) (Littell et al., 1996; SAS Institute, 2004). Linear contrasts (e.g., Littell et al., 1996) were applied to specifically test whether the year prior to supplemental swine removal (2003) differed from the two following years with supplemental swine removal, and to annually compare seepage slopes in areas open to hunting with those in areas closed to hunting (without and with removal, respectively). 
To accommodate variables not conforming to normality, Spearman's correlations were calculated to indicate the level of relationship between mean swine damage and the mean cover, mean height, or mean percent occurrence of the other vegetative and habitat variables, depending on whether cover, presence/absence, or stem density was measured in each plot.

Passive tracking indices (PTI) for swine were calculated for 2003-2005. by applying the indexing paradigm presented in Engeman (2005) and specifically applied to tracking plots for swine by Engeman et al. (2001). The mean measurement across plots was calculated for each day. The index values were the means of the daily means:

PTI $=\frac{1}{d} \sum_{j=1}^{d} \frac{1}{s_{j}} \sum_{i=1}^{s_{j}} x_{i j}$

where $x_{i j}$ represents the number of swine intrusions at the ith tracking plot on the jth day, $d$ is the number of days of observation, and $s_{j}$ is the number of plots contributing data on the jth day. SAS PROC VARCOMP, using restricted maximum likelihood estimation (REML) (SAS Institute, 2004) was used to calculate the variance components (Searle et al., 1992) needed in the variance estimation formula (Engeman, 2005). Note that independence among plots or among days is not required for these calculations (Engeman, 2005). PTI values were calculated for Eglin AFB as a whole, and not for hunted and unhunted areas separately. Because swine could move freely between the hunted and unhunted areas, attempting to define separate index values for those areas would have had little meaning.
(Zerbe and Dively, 1994), leads to credible habitat valuations and has been successfully applied to other special, protected wetland habitats damaged by swine in Florida (Engeman et al., 2003b, 2004b). Because seepage slopes are an uncommon wetland type, they are not specifically listed in the surveys provided by King (1998). Therefore, we used the median figure over the listed wetland types as the "willingness to pay" value for restoration. The 2005 value for this restoration cost estimate after adjusting for a $3 \%$ annual rate of inflation since the values were presented was $\$ 244,782 /$ ha (Zerbe and Dively, 1994; King, 1998).

\subsection{Economic analyses}

A benefit-cost analysis (BCA) was used to determine in monetary terms the net benefit of swine removal relative to its cost (Zerbe and Dively, 1994; Boardman et al., 1996; Nas, 1996). Reduction of swine damaged habitat is seen as a benefit. In other words, if management action in the form of swine removal reduced the amount of swine-damaged seepage slope habitat, then the benefit of that management effort is the monetary value of that amount of habitat versus the costs of the effort. The BCA of the swine removal involved estimating the benefit-cost ratio (BCR), measured as the value of the reduction in area of seepage slopes suffering swine damage from 2003 to each of the years with swine removal, versus the cost of the swine removal. The analyses were carried out for hunted and unhunted areas separately, as well as their combination. For example, the equation to calculate benefitcost ratios BCRs for the first year of removal can be written as:

$\mathrm{BCR}=\frac{(\mathrm{US} \$ \text { value of pre-removal damage }- \text { US } \$ \text { value of } 2004 \text { swine damage })}{\text { US } \$ \text { cost of swine removal }}$

\subsection{Damage valuations}

Credible valuation of special habitats is not straight-forward (Engeman et al., 2004a). Special habitats such as wetlands have limited market value, and when selectively protected, the market value diminishes further (King, 1998). Nevertheless, multiple approaches have been considered for valuing such habitat. The use of contingent valuation surveys is a common economic procedure, but for special habitats it tends to provide abstract appraisals of habitat value (King, 1998), and rarely forms the basis for policy decisions (Adamowicz, 2004).

One defensible, logical, and applicable valuation for damaged habitat is to use expenditure data for permitted mitigation projects. Such data represent an empirical demonstration of willingness-to-pay value, and are most generally available for wetland habitats. The US dollar amounts per unit area spent in efforts to restore various wetland habitat types has been presented by King (1998). The numbers represent the US dollar amounts that environmental regulators, and to a degree elected governments, have allowed permit applicants to spend in attempts to replace lost wetland services and values (King, 1998). Use of these figures, coupled with appropriate adjustments for annual rates of inflation
Swine were removed by agreement between WS and Eglin AFB. The objectives for entering into the swine removal agreement were to protect multiple special habitats from swine damage, including seepage slopes, steephead ravines, and some small sites also vulnerable to swine damage. Approximately $65 \%, 30 \%$, and $5 \%$ of removal effort and resources were respectively directed towards seepage slopes, steephead ravines, and the other situations. The total amounts paid for the two years of control were respectively $\$ 95,301$ and $\$ 120,000$. Thus, the proportional amounts assigned for protection of seepage slopes were $\$ 61,946$ and $\$ 78,000$, respectively.

\section{Results}

\subsection{Damage and habitat variables}

An interaction effect between sport hunting and years demonstrated a rapid convergence to similar low damage levels from higher, disparate initial damage levels in the hunted and unhunted areas (Table 2, $F=6.42, \mathrm{df}=2,52.1, p=0.003$ ). In the 1.7 years after implementing supplemental swine removal, 631 swine were removed from the unhunted areas 
Table 2 - Estimated damage and root exposure to seepage slopes in the hunted and unhunted portions of Eglin Air Force Base (AFB) before (2003) and subsequent to commencement of supplemental swine removal $(2004,2005)$

\begin{tabular}{|c|c|c|c|c|c|c|}
\hline \multirow[t]{2}{*}{ Year } & \multicolumn{2}{|c|}{ Mean damage cover (\%) } & \multicolumn{2}{|c|}{$\%$ Plots with root exposure } & \multirow[t]{2}{*}{ Swine PTI } & \multirow[t]{2}{*}{ \# Swine removed } \\
\hline & Hunted (no control) & Unhunted (control) & Hunted (no control) & Unhunted (control) & & \\
\hline 2003 & 10.5 & 25.0 & 25.3 & 45.7 & 10.72 & NA \\
\hline 2004 & 5.6 & 7.2 & 18.9 & 29.3 & 4.55 & 432 \\
\hline 2005 & 4.3 & 5.6 & 20.6 & 29.0 & 0.82 & 196 \\
\hline
\end{tabular}

Passive tracking index (PTI) values and swine removal through control procedures (not sport hunting) are given for the base for the same time period.

and damage was reduced by $78 \%$ for those seepage slopes (Table 2). In addition, damage was reduced by $60 \%$ in the open hunting area where supplemental removal was not applied (Table 2). By way of contrast with supplemental removal, 92 swine were taken by sport hunting from 2003 to 2005. Prior to initiation of supplemental swine removal, mean damage on seepage slopes in areas open to hunting was less than half that for unhunted slopes (Table 2, $F=13.85, p<0.001)$. Removal was initiated in fall 2003, and by the time post-removal damage was first measured the following spring ( 0.7 year), damage to seepage slopes in the open hunting area had decreased substantially. The damage losses in the closed hunting area experienced a greater decrease to the degree that damage losses in open and closed hunting areas were statistically indistinguishable (Table 2, $F=0.18, p=0.67)$. By 2005, after 1.7 years of removal, swine damage to seepage slopes in open and closed hunting areas each continued to decrease and converge in magnitude $(4.3 \%$ in hunted areas and $5.6 \%$ in unhunted areas, Table 2, $F=0.11, p=0.75)$. Seepage slopes in areas receiving sporthunting pressure, but not supplemental removal obtained significant benefit from the swine removal carried out in the closed hunting zone. This is not surprising because swine were not restricted in their movements between the hunted and unhunted areas. However, we did not expect the rapidity with which the damage levels between hunted and unhunted areas converged. Following implementation of swine removal, the percent of plots with roots exposed also showed substantial declines for seepage slopes in both hunted and unhunted areas (Table 2, $F=7.28, d f=2,53.3$,

Table 3 - Variables showing a detectable Spearman correlation with average swine damage from 28 Seepage slopes at Eglin Air Force Base, Florida

\begin{tabular}{lcc} 
Variable & Spearman's $\rho$ & $p$-Value \\
\hline \% Plots with root exposure & 0.852 & $<0.0001$ \\
Average cover of toothache grass & -0.343 & 0.014 \\
Average cover of wiregrass & -0.218 & 0.046 \\
Average cover of panic grass & 0.201 & 0.067 \\
Average cover of nongraminoids & -0.234 & 0.032 \\
Average total vegetative cover & -0.372 & 0.005 \\
Average cover of bare ground & 0.403 & 0.001 \\
Average cover of saw palmetto & 0.256 & 0.019 \\
\% Plots with whitetop pitcher plants & -0.289 & 0.008 \\
\% Plots with redflower pitcher plants & 0.260 & 0.017 \\
\% Plots with yellow pitcher plants & -0.195 & 0.075 \\
\hline
\end{tabular}

$p=0.002)$. The gap between hunted and unhunted areas narrowed in that time, but an interaction similar to that for damage cover was not detected $(F=1.83, \mathrm{df}=2,53.3$, $p=0.17)$.

Swine damage levels to the seepage slopes displayed at most moderate correlations with the habitat/vegetation variables. Such modest magnitudes for correlations with swine damage can be expected in light of natural variability and the many environmental factors influence plant distributions. Swine damage at seepage slopes had detectable correlations with 11 habitat and vegetative variables (Table 3). Not surprisingly, the percent of plots with root exposure correlated well with swine damage, since swine damage often results in root exposure. Among the variables having detectable correlations with swine damage were the three indicators of seepage slope health: toothache grass, wiregrass and herbaceous cover, each of which was negatively correlated with swine damage. Whitetop pitcher plants are state-listed as endangered in Florida and their presence was negatively correlated with swine damage, as was the correlation for the more common yellow pitcher plant. In contrast, the redflower pitcher plant, state-listed as a threatened species in Florida, was positively correlated with swine damage.

\subsection{Economic analyses}

The mean area of the 28 sampled seepage slopes was 0.516 ha (s.e. $=0.107$ ). Of the 237 seepage slopes on Eglin AFB, 117 are in areas open to hunting and 120 are in areas closed to hunting, resulting in estimates of 61.9 ha total of seepage slope habitat in the closed-to-hunting area and 60.4 ha in the open hunting area. The estimated total area of damage across all seepage slopes was reduced by two-thirds in unhunted areas, and halved in hunted areas. Further reductions in each area followed another year of removal (Table 4). Application of economic values to area of seepage slopes lost to swine damage revealed a $\$ 3.4$ million reduction in damage losses over the combined areas in the first year of supplemental removal, and \$3.8 million over both years with supplemental removal (Table 4). Both figures are substantial in comparison to the costs for removal: $\$ 62,000$ for the first year and $\$ 140,000$ for both years combined, producing first-year and overall BCRs of 55.2 and 27.5, respectively (Table 4). The figures for the second year take into account only the further reduction in damage beyond the first year of removal, and do not include cumulative benefits obtained during the first year of removal. 
Table 4 - Estimated total area of swine damage to seepage slopes in the hunted and unhunted portions of Eglin Air Force Base (AFB) before (2003) and subsequent to commencement of supplemental swine removal $(2004,2005)$

\begin{tabular}{|c|c|c|c|c|c|c|c|}
\hline \multirow[t]{2}{*}{ Year } & \multicolumn{2}{|c|}{ Open to hunting (no control) } & \multicolumn{2}{|c|}{ Closed to hunting (control) } & \multicolumn{2}{|c|}{ Combined } & \multirow[t]{2}{*}{ BCR of control } \\
\hline & $\begin{array}{c}\text { Area of } \\
\text { damage (ha) }\end{array}$ & $\begin{array}{c}\text { Value of } \\
\text { damage (\$) }\end{array}$ & $\begin{array}{c}\text { Area of } \\
\text { damage (ha) }\end{array}$ & $\begin{array}{c}\text { Value of } \\
\text { damage (\$) }\end{array}$ & $\begin{array}{c}\text { Area of } \\
\text { damage(ha) }\end{array}$ & $\begin{array}{c}\text { Value of } \\
\text { damage (\$) }\end{array}$ & \\
\hline 2003 & 6.34 & $1,551,918$ & 15.48 & $3,789,225$ & 21.82 & $5,341,143$ & NA \\
\hline 2004 & 3.38 & 827,363 & 4.46 & $1,091,728$ & 7.84 & $1,919,091$ & 55.2 \\
\hline 2005 & 2.60 & 636,433 & 3.47 & 849,394 & 6.07 & $1,485,827$ & 27.5 \\
\hline
\end{tabular}

Estimated values of swine damage and the benefit-cost ratios for supplemental removal are also given for each year. Supplemental removal was initiated in the unhunted portions of Eglin AFB in 2003 after the damage measurements were completed.

\section{Discussion}

Seepage slopes are an imperiled wetland habitat in Florida (FNAI, 1990; Kindell et al., 1997), and feral swine are one of the destructive forces that threaten those that remain (Kindell et al., 1997; United States Air Force, 2002). Sport hunting for swine has always been in place at Eglin AFB, and swine management in the early 1960's was focused on increasing swine populations and improving genetics (e.g., Natural Resources, 1965). Besides recreation, sport hunting is now also viewed as a tool to curb swine populations. The results from our initial year of study (prior to commencing supplemental swine removal) indicated sport hunting had a beneficial effect towards reducing swine damage. However, managing a game animal for recreational purposes encompasses different objectives than managing a habitat for conservation. Hence, sport hunting over the three years of study removed less than $13 \%$ of the swine as removed by the supplemental removal effort in under two years. The differential impacts from the different management objectives are evidenced by the rapid benefit from supplemental swine removal applied only in the area closed to hunting.

Funding to manage feral swine and restore habitat is finite and must be carefully managed to optimize the positive impact on the protected resources. The use of the PTI has effectively aided the optimization of the timing and placement of removal activities in other damage reduction situations, in addition to monitoring population trends (e.g., Engeman et al., 2003). Similarly for Eglin AFB, the information gained from the PTI tracking plots facilitated economical deployment of resources for swine removal over a large area by indicating, based on activity, when and where traps should be placed and removed. In a broader fiscal context, administrative decisions on management actions towards destructive invasive species are based on economic constraints in addition to need. However, the metric for success of management actions is measured in resource quality. Therefore, estimation of feral swine damage levels, and application of a monetary value to the damage permits economic analyses to help guide and evaluate management actions. Here, we not only quantified damage by feral swine to the significant remnants of seepage slope habitat in Florida, but we also applied economic valuations to the damage and assessed the benefit-costs of introducing a management action (swine removal) for conserving seepage slope habitat. Economic benefits, as measured by the value of reductions in damage in the controlled area, were over $\$ 2.6$ million after initiation of removal. The ancillary benefit from the same management action was damage reduction in the open hunting area, valued at nearly threequarters of a million dollars (Table 4).

The initial impacts of a removal program would be expected to be the most noticeable, especially with damage so quickly reduced. Nevertheless, the value of the reduction in losses between the first and second years of removal was still over $\$ 430,000$. Due to the high reproductive potential of feral swine, the accrued benefits of removal could rapidly be lost. Therefore, the environmental and economic benefits of succeeding years of removal should be viewed not only in terms of subsequent reductions in damage levels, but also in terms of accrued value for maintaining damage at current low levels.

\section{Acknowledgement}

We wish to thank Scott Hardin and two anonymous reviewers for their suggestions which profoundly improved this paper.

\section{R E F E R E N C E S}

Adamowicz, W., 2004. What's it worth?: An examination of historical trends and future directions in environmental valuation. Australian Journal of Agricultural and Resource Economics 48, 419-443.

American Veterinary Medical Association, 2001. 2000 Report of the AVMA Panel on Euthanasia. Journal of the American Veterinary Medical Association 218, 669-696.

Boardman, A.E., Greenberg, D.H., Vining, A.R., Weimer, D.L., 1996 Cost-Benefit Analysis: Concepts and Practice. Prentice Hall, Upper Saddle River, New Jersey.

Bratton, S.P., 1977. Wild hogs in the United States - origin and nomenclature. In: Wood, G.W. (Ed.), Research and Management of Wild Hog Populations. The Belle W. Baruch Forest Science Institute of Clemson University, Georgetown, South Carolina, pp. 1-4.

Choquenot, D., McIlroy, J., Korn, T., 1996. Managing Vertebrate Pests: Feral Pigs. Bureau of Resource Sciences. Australian Government Publishing Service, Canberra, ACT.

Conger, T.H., Young, E., Heckmann, R.A., 1999. Brucella suis in feral swine. In: Proceedings of the 1999 National Feral Swine Symposium. Texas Animal Health Commission, Austin, Texas, pp. 98-107.

Engeman, R.M., 2005. A methodological and analytical paradigm for indexing animal populations applicable to many species and observation methods. Wildlife Research 32, 203-210. 
Engeman, R.M., Constantin, B., Nelson, M., Woolard, J., Bourassa, J., 2001. Monitoring changes in feral swine population and spatial distribution of activity. Environmental Conservation. 28, 235-240.

Engeman, R.M., Martin, R.E., Constantin, B., Noel, R., Woolard, J., 2003. Monitoring predators to optimize their management for marine turtle nest protection. Biological Conservation. 113, 171-178.

Engeman, R.M., Smith, H.T., Shwiff, S.A., Constantin, B.U., Nelson, M., Griffin, D., Woolard, J., 2003b. Prevalence and economic value of feral swine damage to native habitat in three Florida state parks. Environmental Conservation 30, 319-324.

Engeman, R.M., Shwiff, S.A., Smith, H.T., Constantin, B.U., 2004a. Monetary valuation of rare species and imperiled habitats as a basis for economically evaluating conservation approaches. Endangered Species Update 21, 66-73.

Engeman, R.M., Smith, H.T., Severson, R., Severson, M.A., Woolard, J., Shwiff, S.A., Constantin, B.U., Griffin, D., 2004b. Damage reduction estimates and benefit-cost values for feral swine control from the last remnant of a basin marsh system in Florida. Environmental Conservation 31, 207-211.

Florida Natural Areas Inventory (FNAI). 1990. Guide to the natural communities of Florida. Florida Natural Areas Inventory and Florida Department of Natural Resources, Tallahassee, Florida.

Gipson, P.S., Hlavachick, B., Berger, T., Lee, C.D., 1997. Explanations for recent range expansions by wild hogs into midwestern states. Great Plains Wildlife Damage Control Workshop 13, 148-150.

Harper, M.G., Trame, A.-T., Hohmann, M.G., 1998. Management of herbaceous seeps and wet savannas for threatened and endangered species. USACERL Technical Report 98/70. US Army Corps of Engineers, Washington, D.C.

Hellgren, E., 1999. Reproduction in feral swine. In: Proceedings of the 1999 National Feral Swine Symposium. Texas Animal Health Commission, Austin, Texas, pp. 67-68.

Kindell, C.E., Herring, B.J., Nordman, C., Jensen, J., Schotz, A.R., Chafin, L.G. 1997. Natural community survey of Eglin Air Force Base, 1993-1996: Final Report. Florida Natural Areas Inventory, Tallahassee, Florida.

King, D., 1998. The dollar value of wetlands: trap set, bait taken, don't swallow. National Wetlands Newsletter (July-August), 711.

Kliejunas, J.T., Ko, W.H., 1976. Dispersal of Phytophthora cinnamomi on the island of Hawaii. Phytopathology 66, 457-460.

Littell, R.C., Milliken, G.A., Stroup, W.W., Wolfinger, R.D., 1996. SAS System for Mixed Models. SAS Institute, Cary, North Carolina.

McLean, R.A., Sanders, W.L., Stroup, W.W., 1991. A unified approach to mixed linear models. The American Statistician $45,54-64$.

Nas, T.F., 1996. Cost-Benefit Analysis: Theory and Application. Sage Publications, Thousand Oaks, CA.
Natural Resources 1965. The proving ground for conservation. Fish and Wildlife Conservation Program. Eglin Air Force Base, Florida.

Pearson, D.E., Ruggiero, L.F., 2003. Transect versus grid trapping arrangements for sampling small mammal communities. Wildlife Society Bulletin 31, 454-459.

Romero, C.H., Meade, P.N., 1999. Pseudorabies virus in feral swine: a research update. In: Proceedings of the 1999 National Feral Swine Symposium. Texas Animal Health Commission, Austin, Texas, pp. 73-74.

Ryan, D.A., Heyward, A., 2003. Improving the precision of longitudinal ecological surveys using precisely defined observational units. Environmetrics 14, 283-293.

SAS Institute. 2004. SAS/STAT User's Guide 9.1. SAS Institute, Carey, North Carolina.

Searle, S.R., Casella, G., McCulloch, C.E., 1992. Variance Components. Wiley \& Sons, New York.

Seward, N., VerCauteren, K., Witmer, G., Engeman, R., 2004. Feral swine impacts on agriculture and the environment. Sheep and Goat Research Journal 19, 34-40.

Taft, A.C., 1999. Feral swine - national concerns. In: Proceedings of the 1999 National Feral Swine Symposium. Texas Animal Health Commission, Austin, Texas, pp. 2526.

Thompson, S.K., 2002. Sampling. Wiley \& Sons, New York.

Towne, C.W., Wentworth, E.N., 1950. Pigs from Cave to Cornbelt. University of Oklahoma Press, Norman, Oklahoma.

United States Air Force. 2002. Integrated Natural Resources Management Plan. Eglin Air Force Base, Florida.

US Congress. 1993. Harmful Non-indigenous Species in the United States. Office of Technology Assessment, OTA-F-565, Government Printing Office, Washington, D.C.

US Department of Agriculture/Animal and Plant Health Inspection Service, US Department of Agriculture/Forest Service and Department of Interior/Bureau of Land Management. 1997. Animal Damage Control Program Final Environmental Impact Statement (Revised). USDA/Animal and Plant Health Inspection Service. Washington, D.C.

US Department of Agriculture, 1999. Wild pigs hidden danger for farmers and hunters. Animal and Plant Health Inspection Services Information Bulletin 620. Washington, D.C.

Winer, B.J., 1971. Statistical Principles in Experimental Design. McGraw-Hill, New York.

Wolfinger, R.D., Tobias, R.D., Sall, J., 1991. Mixed models: a future direction. In: Proceedings of the 16th SAS Users Group Conference. SAS Institute, Carey, North Carolina, pp. 13801388.

Wood, G.W., Barrett, R.H., 1979. Status of wild pigs in the United States. Wildlife Society Bulletin 7, 237-246.

Zerbe, R.O., Dively, D.D., 1994. Benefit-Cost Analysis: In: Theory and Practice. Harper Collins College Publishers, New York. 